\title{
Tingkat Kecukupan Energi, Protein Dan Status Ketahanan Pangan Rumah Tangga Berhubungan Dengan Status Gizi Anak Usia 6-8 Tahun
}

\section{Levels Adequacy of Energy and Protein and Household Food Security Status with Nutritional Status of Children Aged 6-8 Years}

\author{
Rika Kusuma Nagari*1 $^{1}$, Triska Susila Nindya ${ }^{1}$
}

\begin{abstract}
ABSTRAK
Latar Belakang: Status gizi anak sekolah dasar dapat dipengaruhi oleh banyak faktor diantaranya tingkat kecukupan energi dan protein serta status ketahanan pangan rumah tangga. Ketidakseimbangan tingkat kecukupan energi dan protein, kemungkinan dapat menyebabkan masalah gizi pada anak. Status ketahanan pangan rumah tangga berdampak kepada kemampuan dalam mengakses pangan yang baik.

Tujuan: Penelitian ini bertujuan untuk menganalisis hubungan antara tingkat kecukupan energi dan protein serta status ketahanan pangan rumah tangga dengan status gizi anak usia 6-8 tahun.

Metode: Penelitian ini menggunakan desain cross sectional dengan sampel sebanyak 62 keluarga yang memiliki anak usia 6-8 tahun yang terdaftar di SDN 1 dan 2 Sambirejo. Pengukuran antropometri tinggi badan dan berat badan digunakan untuk mengetahui status gizi anak. Selain itu, instrumen yang digunakan adalah formulir 2x24-hours food recall (tingkat kecukupan energi dan protein), dan US-HFSSM (status ketahanan pangan rumah tangga). Statistik uji yang digunakan adalah uji korelasi spearman.

Hasil: Hasil dari penelitian ini yaitu terdapat hubungan antara tingkat kecukupan energi $(p=0,000)$ dan protein $(p=0,000)$ serta status ketahanan pangan rumah tangga $(p=0,010)$ dengan status gizi anak.

Kesimpulan: Rumah tangga yang rawan pangan akan memiliki risiko mengalami masalah gizi yang lebih tinggi bila dibandingkan dengan rumah tangga yang tahan pangan, sehingga perlu adanya pemberian makanan tambahan kepada anak, terutama kepada anak yang memiliki masalah gizi dan berada pada kondisi rawan pangan. Hal tersebut dimaksudkan untuk memberikan anak tambahan makanan yang bergizi agar menurunkan risiko masalah gizi.
\end{abstract}

Kata Kunci: tingkat kecukupan energi, tingkat kecukupan protein, status gizi anak, status ketahanan pangan rumah tangga 


\begin{abstract}
Background: The nutritional status of elementary school children can be influence by many factors such as levels adequacy of energy and proteinand household food security status. Unbalanced levels adequacy of energy and protein possibility can cause nutritional problems in children. While the status of household food security has an impact on the household ability to access a good food.

Objectives: aims of this study are to analyze the relationship between nutritional adequacy level and household food security status with nutritional status of children aged 6-8 years.

Method: This study used cross sectional design with sample of 62 families with children aged 6-8 years enrolled in SDN 1 and 2 Sambirejo. Anthropometric measurement of height and weight is used to determine the nutritional status of children. The instruments used $2 \times 24$-hours food recall form (energy and protein adequacy level), and US-HFSSM (household food security status). While the statistical test used is spearman correlation test.

Results: The results showed a correlation between levels of energy $(p=0.000)$ and protein $(p=0.000)$ adequacy and household food security status $(p=0.010)$ with child nutritional status.

Conclusion: Households with food insecurity had a higher proportion of nutritional problem than food secure family, so it is needed to children for having supplemental food, especially them who have nutritional problems and on food insecurity condition. It is intended to provide children with additional nutritious food to reduce the risk of nutritional problems.
\end{abstract}

Keywords: level adequacy of energy, level adequacy of protein, nutritional status, household food security status

\footnotetext{
*Koresponden:

rikanagari23@gmail.com

${ }^{1}$ Departemen Gizi Kesehatan, Fakultas

Kesehatan Masyarakat-Universitas Airlangga
} 


\section{PENDAHULUAN}

Peningkatan derajat kesehatan terutama gizi masyarakat, dapat menjadi sarana pemerintah Indonesia untuk mengupayakan peningkatan dan perbaikan kualitas sumber daya manusia. Aset potensial dalam proses pembangunan bangsa salah satunya adalah anak ${ }^{1}$. Upaya yang dapat dilakukan yaitu memberikan azupan zat gizi yang cukup kepada anak melalui pemberian makanan tambahan agar perkembangan anak dapat berjalan optimal. Masalah gizi pada anak akan muncul apabila kecukupan gizi tidak terpenuhi ${ }^{2}$. Data Riskesdas tahun 2013 menyebutkan bahwa prevalensi gizi kurus dan gemuk pada anak sekolah (5-12 tahun) di tingkat nasional sebesar $11,2 \%$ dan $10,8 \%$, sedangkan prevalensi gizi kurus dan gemuk di Provinsi Jawa Timur masing-masing sebesar $12 \%^{3}$. Selain itu, berdasarkan survey PSG tahun 2015, didapatkan bahwa prevalensi gizi kurus di kabupaten Trenggalek sebesar 8,3\%. Nilai prevalensi gizi kurus yang ada di Kabupaten Trenggalek berada di bawah Jawa Timur dan Nasional. Meskipun demikian, bukan berarti masalah tersebut dapat diabaikan tetapi tetap harus diperhatikan agar anak yang mengalami masalah gizi tidak mengalami gangguan terkait umbuh kembangnya. Asupan yang tidak seimbang antara yang dimakan dan yang dimanfaatkan oleh tubuh, dapat mempengaruhi status gizi anak ${ }^{4}$. Selain itu, pola konsumsi seseorang dapat dipengaruhi oleh keadaan status ketahanan pangan ${ }^{5}$. Status ketahanan pangan ini dapat dipengaruhi oleh tingkat ekonomi. Keterbatasan ekonomi dapat berpengaruh kepada akses pangan dari segi kuantitas dan kualitasnya ${ }^{6}$.

Penelitian ini bertujuan untuk menganalisis hubungan antara tingkat kecukupan energi dan protein serta status ketahanan pangan rumah tangga dengan status gizi anak usia 6-8 tahun di SDN 1 dan 2 Sambirejo Kecamatan Trenggalek, Kabupaten Trenggalek. Lokasi ini dipilih karena sebagian besar siswa berasal dari keluarga dengan ekonomi menengah kebawah, sehingga diperkirakan anak tersebut akan mengalami kerentanan terhadap masalah gizi.

\section{METODE}

Penelitian ini merupakan penelitian observasional analitik dengan desain cross sectional. Populasi awal penelitian ini berjumlah 88 siswa dan berasal dari keluarga yang memiliki anak berusia 6-8 tahun yang terdaftar sebagai siswa di Sekolah Dasar Negeri 1 dan 2 Sambirejo Kecamatan Trenggalek, Kabupaten Trenggalek. Pengambilan data dilakukan pada bulan Mei 2017. Teknik sampling yang digunakan adalam simple random sampling. Sampel minimal yang dibutuhkan adalah 62 anak yang dihitung menggunakan rumus estimasi proporsi dengan $\alpha=0,05$, proporsi prevalensi $0,8^{7}$, dan presisi $10 \%$.

Instrumen yang digunakan adalah formulir biodata responden, formulir $2 \times 24$ hours food recall, dan kuesioner United StatesHousehold Food Security Survey Modul (USHFSSM). Formulir biodata responden digunakan untuk mencatat karakteristik anak (nama, usia, jenis kelamin) dan karakteristik orang tua (nama, usia, dan tingkat pendidikan). Formulir 2x24-hours food recall digunakan untuk mencatat konsumsi makanan dan minuman anak selama 24 jam terakhir. Hasil 2x24-hours food recall kemudian diklasifikasikan menjadi cukup ( $\geq 77 \% A K G$ ) dan kurang $(<77 \% A K G)^{8}$. Kuesioner US-HFSSM digunakan untuk menyatakan status ketahanan pangan rumah tangga. Status ketahanan pangan rumah tangga diklasifikasikan menjadi tahan pangan (skor: $0)$, rawan pangan tanpa kelaparan (skor: 1-2), rawan pangan dengan derajad kelaparan sedang (skor: 3-7), dan rawan pangan dengan derajad kelaparan berat (skor: 8-18) ${ }^{9}$. Selain itu, pengukuran antropometri meliputi tinggi badan dan berat badan dilakukan untuk menilai status gizi anak. Status gizi anak diklasifikasikan menjadi Sangat kurus $(<(-3)$ $S D)$, kurus ((-3) SD sampai dengan < (-2) SD), normal ((-2) SD sampai dengan $1 \mathrm{SD})$, gemuk (>1 SD sampai dengan $2 \mathrm{SD}$ ) dan obesitas (> 2 $\mathrm{SD})^{10}$. Uji korelasi spearman $(\alpha=0,05)$ digunakan untuk menguji hubungan antar variabel.

Penelitian yang telah dilakukan ini memiliki kelebihan dan kelemahan. Kelebihan 
dari penelitian ini adalah belum ada publikasi lain yang sejenis. Penelitian ini juga memiliki kelemahan yaitu tidak meneliti variabel lain yang dapat mempengaruhi status gizi anak meliputi aktivitas fisik. Selain itu, penelitian ini hanya memfokuskan kepada akses pangan rumah tangga saja.

\section{HASIL DAN PEMBAHASAN}

Anak yang terpilih untuk mengikuti penelitian ini berusia $7-<8$ tahun $(53,2 \%)$, berjenis kelamin perempuan $(51,6 \%)$ dan berada di kelas 1 dan 2 sekolah dasar. Pada usia ini, mulai terdapat peningkatan aktifitas fisik, asupan makanan, dan preferensi makanan juga mulai mampak pada usia ini. Kebutuhan asupan makanan anak, dapat dipengaruhi oleh faktor usia, jenis kelamin, dan aktifitas fisik ${ }^{11,12}$. Hasil penelitian pada tabel 1 yang telah dilakukan menunjukkan bahwa prevalensi gizi lebih banyak terdapat pada laki-laki bila dibandingkan dengan perempuan. pernyataan tersebut sesuai dengan hasil penelitian yang menyebutkan bahwa prevalensi masalah gizi obesitas lebih banyak terjadi pada laki-laki ${ }^{12,13}$. Hal tersebut terjadi karena konsumsi energi dan protein lebih banyak pada laki-laki daripada perempuan ${ }^{12}$.

Tabel 1. Distribusi Jumlah Responden Menurut Karakteristik Anak dan Keluarga di SDN 1 dan 2 Sambirejo Kecamatan Trenggalek, Kabupaten Trenggalek Tahun 2017

\begin{tabular}{|c|c|c|}
\hline \multirow{2}{*}{ Karakteristik } & \multicolumn{2}{|c|}{ Jumlah Responden } \\
\hline & $\mathbf{n}$ & $\%$ \\
\hline \multicolumn{3}{|l|}{ Usia Anak (tahun) } \\
\hline $6-<7$ & 24 & 38,7 \\
\hline $7-<8$ & 33 & 53,2 \\
\hline$\geq 8$ & 5 & 8,1 \\
\hline Total & 62 & 100,0 \\
\hline \multicolumn{3}{|l|}{ Jenis Kelamin Anak } \\
\hline Laki-laki & 30 & 48,4 \\
\hline Perempuan & 32 & 51,6 \\
\hline Total & 62 & 100 \\
\hline \multicolumn{3}{|l|}{ Tingkat Pendidikan Orang Tua } \\
\hline \multicolumn{3}{|l|}{ Tingkat Pendidikan Ayah } \\
\hline Tidak tamat SD/MI/sederajat & 1 & 1,6 \\
\hline Tamat SD/MI/sederajat & 18 & 29,0 \\
\hline Tamat SMP/MTS/sederajat & 24 & 38,7 \\
\hline Tamat SMA/MAN/sederajat & 18 & 29,0 \\
\hline Tamat Perguruan Tinggi & 2 & 1,6 \\
\hline Total & 62 & 100,0 \\
\hline \multicolumn{3}{|l|}{ Tingkat Pendidikan Ibu } \\
\hline Tidak tamat SD/MI/sederajat & 1 & 1,6 \\
\hline Tamat SD/MI/sederajat & 8 & 12,9 \\
\hline Tamat SMP/MTS/sederajat & 26 & 41,9 \\
\hline Tamat SMA/MAN/sederajat & 26 & 41,9 \\
\hline Tamat Perguruan Tinggi & 1 & 1,6 \\
\hline Total & 62 & 100,0 \\
\hline
\end{tabular}


Tingkat pendidikan terakhir kedua orang tua adalah SMP/MTS/sederajat (ayah $(38,7 \%)$ dan ibu $(41,9 \%))$. Orang tua yang memiliki riwayat pendidikan yang tinggi, cenderung akan memiliki pendapatan diatas rata-rata, sehingga risiko terjadi rawan pangan rendah $^{14}$. Semakin tinggi tingkat pendidikan kepala keluarga, maka kemampuan yang dimiliki rumah tangga untuk mengakses pangan juga semakin tinggi ${ }^{15}$. Selain itu, tingkat pendidikan juga dapat mempengaruhi kemampuan seseorang dalam memahami ilmu pengetahuan. Tingkat pendidikan seseorang yang rendah, akan menyebabkan kesulitan dalam memahami pengetahuan termasuk pengetahuan terkait gizi ${ }^{16}$.

Tabel 2. Distribusi Jumlah Responden Menurut Status Gizi Anak SDN 1 dan 2 Sambirejo Kecamatan Trenggalek Kabupaten Trenggalek Tahun 2017

\begin{tabular}{lcc}
\hline \multirow{2}{*}{$\begin{array}{c}\text { Status Gizi } \\
\text { (IMT/U) }\end{array}$} & \multicolumn{2}{c}{ Jumlah Responden } \\
\cline { 2 - 3 } Kurus & 20 & n \\
Normal & 22 & 32,3 \\
Gemuk & 13 & 35,5 \\
Obesitas & 7 & 21,0 \\
\hline Total & $\mathbf{6 2}$ & 11,3 \\
\hline
\end{tabular}

Status gizi merupakan suatu keadaan yang timbul pada individu yang disebabkan oleh konsumsi, dan pemanfaatan zat gizi yang berasal dari bahan makanan atau suplement gizi ${ }^{17}$. Tabel 2 menunjukkan bahwa sebagian besar anak memiliki status gizi normal $(35,5 \%)$. Nilai prevalensi gizi kurus (32\%) dan lebih (32\%) di SD 1 dan 2 Sambirejo lebih tinggi bila dibandingkan dengan prevalensi gizi kurus dan lebih di regional Jawa Timur dan nasional. Kekurangan asupan zat gizi terutama energi dapat menyebabkan gizi kurang dan sebaliknya bila asupannya berlebih, akan menyebabkan kegemukan ${ }^{18}$. Tabel 3 menunjukkan tingkat kecukupan energi dan protein responden adalah kurang $(82,3 \%$ dan
$56,5 \%)$. Tingkat kecukupan energi dan protein yang kurang dapat menyebabkan berbagai masalah gizi yaitu anemia, berat badan lebih dan berat badan kurang ${ }^{11}$.

Tabel 3. Distribusi Jumlah Responden Menurut Tingkat Kecukupan Energi, Dan Protein Anak SDN 1 dan 2 Sambirejo Kecamatan Trenggalek, Kabupaten Trenggalek Tahun 2017

\begin{tabular}{lcc}
\hline Tingkat kecukupan & \multicolumn{2}{c}{ Jumlah Responden } \\
\cline { 2 - 3 }$\quad$ & $\mathbf{n}$ & $\mathbf{\%}$ \\
\hline Zat Gizi & & \\
$\quad$ Kurang & 51 & 82,3 \\
$\quad$ Cukup & 11 & 17,7 \\
\hline Total & 62 & 100 \\
\hline Tingkat kecukupan Protein & & \\
$\quad$ Kurang & 35 & 56,5 \\
$\quad$ Cukup & 27 & 43,5 \\
\hline Total & 62 & 100 \\
\hline
\end{tabular}

Data pada tabel 4 menunjukkan bahwa anak yang memiliki tingkat kecukupan energi kurang memiliki status gizi normal $(43,2 \%)$, sedangkan anak yang tingkat kecukupan energinya cukup memiliki status gizi gemuk (100,00\%). Hasil uji statistik menunjukkan adanya hubungan antara tingkat kecukupan energi dengan status gizi ( $p=$ 0,000 ). Tingkat kecukupan energi yang kurang pada anak SD, dapat menyebabkan status gizi anak berada pada kondisi kurus dan normal ${ }^{19}$. Selain itu, obesitas pada anak dapat dipengaruhi oleh pola konsumsi yang dimiliki oleh anak ${ }^{21}$.

Penelitian yang telah dilakukan oleh Yamin (2013) menunjukkan bahwa tingkat kecukupan energi yang cukup sampai dengan tinggi, akan menyebabkan obesitas pada siswa di Manado ${ }^{22}$. Hal tersebut disebabkan karena ketika asupan energi yang masuk kedalam tubuh melebihi yang dibutuhkan, maka kelebihan asupan tersebut oleh tubuh akan disimpan menjadi lemak di jaringan adiposa ${ }^{23}$. 
Tabel 4. Hubungan antara Tingkat kecukupan Energi dan Protein dengan Status Gizi Anak di SDN 1 dan 2 Sambirejo Kecamatan Trenggalek, Kabupaten Trenggalek

\begin{tabular}{|c|c|c|c|c|c|c|c|c|c|}
\hline \multirow{3}{*}{ Tingkat Kecukupan Zat Gizi } & \multicolumn{6}{|c|}{ Status Gizi (IMT/U) } & \multicolumn{2}{|c|}{ Total } & \multirow{3}{*}{ Nilai $p$} \\
\hline & \multicolumn{2}{|c|}{ Kurus } & \multicolumn{2}{|c|}{ Normal } & \multicolumn{2}{|c|}{ Gemuk } & \multirow{2}{*}{$\mathbf{N}$} & \multirow{2}{*}{$\%$} & \\
\hline & $\mathbf{n}$ & $\%$ & $\mathbf{n}$ & $\%$ & $\mathbf{n}$ & $\%$ & & & \\
\hline \multicolumn{10}{|l|}{ Tingkat kecukupan Energi } \\
\hline Kurang & 20 & 39,2 & 22 & 43,2 & 9 & 17,6 & 51 & 100,0 & \multirow{2}{*}{0,000} \\
\hline Cukup & 0 & 0,0 & 0 & 0,0 & 11 & 100,0 & 11 & 100,0 & \\
\hline \multicolumn{10}{|l|}{ Tingkat kecukupan Protein } \\
\hline Kurang & 19 & 54,3 & 14 & 40,0 & 2 & 5,7 & 35 & 100,0 & \multirow{2}{*}{0,000} \\
\hline Cukup & 1 & 3,7 & 8 & 29,6 & 18 & 66,7 & 27 & 100,0 & \\
\hline
\end{tabular}

Tabel 5. Distribusi Jumlah Responden Menurut Status Ketahanan Pangan Rumah Tangga Orang Tua Siswa SDN 1 dan 2 Sambirejo Kecamatan Trenggalek, Kabupaten Trenggalek Tahun 2017

\begin{tabular}{lrc}
\hline \multirow{2}{*}{ Status Ketahanan Pangan Rumah Tangga } & \multicolumn{2}{c}{ Jumlah Responden } \\
\cline { 2 - 3 } & $\mathbf{n}$ & $\mathbf{\%}$ \\
\hline Tahan pangan & 6 & 9,7 \\
Rawan pangan tanpa kelaparan & 19 & 30,6 \\
Rawan pangan dengan derajat kelaparan sedang & 26 & 41,9 \\
Rawan pangan dengan derajat kelaparan berat & 11 & 17,7 \\
\hline Total & $\mathbf{6 2}$ & $\mathbf{1 0 0 , 0}$ \\
\hline
\end{tabular}

Tabel 6. Hubungan antara Status Ketahanan Pangan Rumah Tangga dengan Status Gizi Anak di SDN 1 dan 2 Sambirejo Kecamatan Trenggalek, Kabupaten Trenggalek Tahun 2017

\begin{tabular}{|c|c|c|c|c|c|c|c|c|c|}
\hline \multirow{3}{*}{$\begin{array}{c}\text { Status Ketahanan Pangan Rumah } \\
\text { Tangga }\end{array}$} & \multicolumn{6}{|c|}{ Status Gizi (IMT/U) } & \multicolumn{2}{|c|}{ Total } & \multirow{3}{*}{ Nilai $p$} \\
\hline & \multicolumn{2}{|c|}{ Kurus } & \multicolumn{2}{|c|}{ Normal } & \multicolumn{2}{|c|}{ Gemuk } & \multirow{2}{*}{$\mathrm{N}$} & \multirow{2}{*}{$\%$} & \\
\hline & $\mathbf{n}$ & $\%$ & $n$ & $\%$ & $\mathbf{n}$ & $\%$ & & & \\
\hline Tahan pangan & 0 & 0,0 & 2 & 33,3 & 4 & 66,7 & 6 & 100,0 & \\
\hline Rawan pangan tanpa kelaparan & 6 & 31,6 & 6 & 31,6 & 7 & 36,8 & 19 & 100,0 & \\
\hline $\begin{array}{l}\text { Rawan pangan dengan derajat } \\
\text { kelaparan sedang }\end{array}$ & 7 & 26,9 & 11 & 42,3 & 8 & 30,8 & 26 & 100,0 & 0,010 \\
\hline $\begin{array}{l}\text { Rawan pangan dengan derajat } \\
\text { kelaparan berat }\end{array}$ & 7 & 63,6 & 3 & 27,3 & 1 & 9,1 & 11 & 100,0 & \\
\hline
\end{tabular}

Anak yang memiliki status gizi kurus $(54,3 \%)$ tingkat kecukupan proteinnya kurang, sedangkan untuk anak dengan tingkat kecukupan protein cukup memiliki status gizi gemuk (66,7\%). Hasil uji statistik menyebutkan adanya hubungan antara tingkat kecukupan protein dengan status gizi anak $(p=0,000)$. Tingkat kecukupan protein yang kurang, menyebabkan anak memiliki status gizi kurus, sedangkan Tingkat kecukupan protein yang cukup, anak memiliki status gizi normal dan gemuk $^{19}$. Pola dan jumlah konsumsi makanan yang salah dapat mengakibatkan tingkat kecukupan zat gizi yang kurang ${ }^{24}$. Konsumsi protein yang tinggi yaitu $>65 \mathrm{gram} / \mathrm{hari}$, dapat menyebabkan risiko kejadian gizi lebih sebanyak dua kali lipat jika dibandingkan dengan mengkonsumsi $<51$ gram $/$ hari $^{25}$.

Status ketahanan pangan rumah tangga pada tabel 5 menunjukkan sebagian besar rawan pangan dengan derajat kelaparan sedang sebesar $41,9 \%$. Selain itu, hasil penelitian juga menunjukkan bahwa rumah tangga yang tahan pangan dan dengan status rawan pangan tanpa kelaparan, memiliki anak dengan status gizi gemuk yaitu $(66,7 \%)$ dan $(36,6 \%)$. Rumah tangga yang berstatus rawan pangan dengan derajat kelaparan sedang, memiliki anak dengan status gizi normal $(42,3 \%)$, sedangkan rumah tangga yang berstatus rawan pangan dengan derajat kelaparan berat, memiliki anak dengan status gizi kurus (63,6\%). Hasil uji statistik 
menyatakan terdapat hubungan yang signifikan antara status ketahanan pangan rumah tangga dengan status gizi anak ( $p=$ $0,010)$. Ketersediaan, akses pangan rumah tangga $^{26}$, stabilitas dan pemanfaatan pangan ${ }^{27}$ memegang peranan penting dalam menentukan status ketahanan pangan rumah tangga ${ }^{26}$. Rumah tangga dengan kondisi ekonomi menengah ke bawah, memiliki kecenderungan tidak tahan pangan atau mengalami rawan pangan ${ }^{28}$. Selain itu, faktor ekonomi dapat berpengaruh terhadap akses terhadap pangan, meskipun bukan faktor satu-satunya ${ }^{29}$. Pendapatan yang dihasilkan oleh orang tua akan mempengaruhi kemampuan rumah tangga dalam mengakses pangan $^{30,31}$. Semakin tinggi status ketahanan pangan rumah tangga, maka semakin tinggi pula akses pangan suatu rumah tangga ${ }^{27}$. Ketahanan pangan rumah tangga berhubungan dengan status gizi siswa $\mathrm{SD}^{32,33}$.

\section{KESIMPULAN}

Karakteristik responden pada penelitian ini adalah pendidikan terakhir orang tua adalah SMP/MTS/sederajat, anak berusia $7-<8$ tahun $(53,2 \%)$ dan berjenis kelamin perempuan $(51,6 \%)$. karakteristik responden tersebut dapat mempengaruhi akses pangan, dan tingkat kecukupan zat gizi sehingga berpengaruh kepada status gizi anak. Asupan energi, protein dan status ketahanan pangan rumah tangga memiliki hubungan dengan status gizi anak. Anak yang memiliki status gizi kurus dan normal, memiliki tingkat asupan energi dan protein kurang dan masuk kedalam kategori rawan pangan dengan derajad sedang dan berat. Anak yang memiliki status gizi gemuk, memiliki tingkat asupan energi dan protein cukup dan masuk kedalam kategori rawan pangan dengan derajad kelaparan sedang. Rumah tangga yang rawan pangan akan memiliki risiko mengalami masalah gizi yang lebih tinggi bila dibandingkan dengan rumah tangga yang tahan pangan, sehingga perlu adanya pemberian makanan tambahan kepada anak, terutama kepada anak yang memiliki masalah gizi dan berada pada kondisi rawan pangan. Hal tersebut dimaksudkan untuk memberikan anak tambahan makanan yang bergizi kepada anak untuk meningkatkan asupan zat gizi terutama energi dan protein. Diperlukan penelitian lanjutan terkait dengan status gizi anak sekolah dasar yang dilihat dari aspek aktifitas fisik anak dan dimensi ketahanan pangan yang lainnya yaitu stabilitas, pemanfaatan, dan keamanan pangan.

\section{ACKNOWLEDGEMENT}

Terima kasih penulis berikan kepada: Badan Kesatuan Bangsa dan Politik Provinsi Jawa Timur dan Kabupaten Trenggalek, Dinas Pendidikan Kabupaten Trenggalek, dan SDN 1 Dan 2 Sambirejo Kecamatan Trenggalek, Kabupaten Trenggalek yang telah memberikan izin untuk pelaksaan penelitian ini. Seluruh staf dan dosen Departemen Gizi Kesehatan dan Program Studi IImu Gizi FKM UNAIR terutama kepada dosen pembimbing atas bimbingan dan pengajaran yang diberikan kepada penulis.

\section{REFERENSI}

1. Nursilmi, dan Kusharto, CM. Hubungan Pola Konsumsi, Status Gizi, Dan Aktivitas Fisik Dengan Kadar Asam Urat Lansia Wanita Peserta Posbindu Sinarsi. Skripsi. Bogor: Fakultas Ekologi Manusia, Institut Pertanian Bogor, 2013; p. 1-3. Available from

http://repository.ipb.ac.id/handle/12345 6789/66309 Diakses pada 2 Juli 2017

2. Khomsan A, Anwar F, Hernawati N, Suhanda NS, \& Oktarina. Tumbuh Kembang Dan Pola Asuh Anak. Bogor: Institut Pertanian Bogor Press, 2013;1: p. 41-50. Available from http://repository.ipb.ac.id/handle/12345 6789/62521 Diakses pada 2 Juli 2017

3. Badan Penelitian Dan Pengembangan Kesehatan Kementrian Kesehatan RI. Riset Kesehatan Dasar Tahun 2013, 2013;1-384. Available from http://www.depkes.go.id/resources/dow nload/general/Hasil\%20Riskesdas\%20201 3.pdf. Diakses pada tanggal 7 Maret 2017

4. Adriani M, \& Wirjatmadi B. Peranan Gizi Dalam Siklus Kehidupan. Jakarta:Kencana 
Prenada Media Group, 2012;2: p. 245278

5. Leyna GH, Mmbaga EJ, Mnyika KS, Hussain A, \& Klepp KI. Food linsecurity is Associated with Food Consumption Patterns and Anthropometric Measures but not Serum Micronutrient levels in adults in rural Tanzania. Public Health Nutrition. 2010; 13(9), 1438-1444. Available from http://www.journals.cambridge.org/abstr act_S1368980010000327 Diakses pada 6 Maret 2017

6. Putri RF, Sulastri D, \& Lestari Y. FaktorFaktor Yang Berhubungan Dengan Status Gizi Anak Balita Di Wilayah Kerja Puskesmas Nanggolo Padang. Jurnal Kesehatan Andalas, 2015;4(1): p. 254261. Available from http://jurnal/fk.unand.ac.id Diakses pada 7 Maret 2017

7. Yuniarti $\mathrm{AM}, \&$ Pamela $\mathrm{Cl}$. Pola Asuh Makan Oleh Ibu Bekerja Dengan Status Gizi Siswa Di SDN Ngrame Kecamatan Pungging Kabupaten Mojokerto. Medica Majapahit, 2016;8(2): p. 9-20. Available from

http://ejurnalp2m.stikesmajapahitmojok erto.ac.id/index.php/MM/article/view/11 1 Diakses pada 3 Maret 2017

8. Gibson, R.S. Principles of Nutritional Assessment. United States of America: Oxford University Press. 2005

9. USDA. US Household Food Security Module: Three-Stage Design with Screeners., [e-book] New York: US Department of Agriculture. 2012 available from https://www.ers.usda.gov/topics/foodnutrition-assistance/food-security-in-theus/survey-tools/ Diakses pada 17 Maret 2017.

10. Kementerian Kesehatan Republik Indonesia. Profil Kesehatan Indonesia Tahun 2011. Jakarta: Badan Penelitian dan Pengembangan Kesehatan Departemen Kesehatan Republik Indonesia. 2015

11. Almatsier S., Soetardjo, S., \& Soekarti, M. Gizi Seimbang Dalam Daur Kehidupan.
Jakarta: Gramedia Pustaka Utama. 2011; p. 480

12. Arisman MB. Buku Ajar Ilmu Gizi: Gizi dalam Daur Kehidupan. Jakarta: Penerbit Buku Kedokteran EGC. 2009;2: p. 275

13. Dewi MR, \& Sidiartha IGL. Prevalensi Dan Faktor Risiko Obesitas Anak Sekolah Dasar Di Daerah Urban Dan Rural. Medicina, 2013;44(1). Available from https://ojs.unud.ac.id/index.php/medicin a/article/view/6832 Diakses pada 2 Juli 2017

14. Ogden $C L$, Carroll MD, Kit BK, \& Flegal KM. Prevalence Of Childhood And Adult Obesity In The United States, 2011-2012. Journal American Medical Association. 2014;311(8), 806-814. Available from http://jama.jamanetwork.com/article.asp x?doi=10.1001/jama.2014.732 Diakses pada tanggal 2 Juli 2017

15. Mangkoeto RR. Analisis Pengaruh Food Coping Strategy Terhadap Ketahanan Pangan Rumah Tangga Petani Di Kabupaten Lebak Banten. Skripsi. Bogor: Fakultas Ekologi Manusia, Institut Pertanian Bogor, 2009; p. 35-49

16. Sihite NW. Analisis Determinan Ketahanan Pangan Rumah tangga di Kota Medan. Skripsi. Bogor: Institut Pertanian Bogor, 2011. Available from http://repository.ipb.ac.id/handle/12345 6789/47434 Diakses pada 13 Maret 2017.

17. Hardinsyah. Review Faktor Determinan Keragaman Konsumsi Pangan. Jurnal Gizi Dan Pangan, 2007;2(2): p. 55-74. Available from http://repository.ipb.ac.id/handle/12345 6789/52502 Diakses pada 7 Maret 2017

18. Gibson RS. Principles of Nutritional Assessment. Oxford University Press, USA. 2005; p. 201-225

19. Misnadiarly. Obesitas Sebagai Faktor Risiko Beberapa Penyakit. Jakarta: Universitas Indonesia Press, 2007; p. 1152

20. Utari LD, Ernalia Y, \& Suyanto. Gambaran Status Gizi Dan Asupan Zat Gizi Pada Siswa Sekolah Dasar Kecamatan Sungai Sembilan Kota Dumai. JOM FK, 2016;3(1): p. 1-17. Available from http://jom.unri.ac.id/index.php/JOMFDO 
K/article/view/9244 Diakses pada 2 Juli 2017

21. Maidelwita Y. Pengaruh Faktor Genetik, Pola Konsumsi Dan Aktivitas Fisik Dengan Kejadian Obesitas Pada Anak Kelas 4-6 SD SBI Percobaan Ujung Gurun Padang. Jurnal Mercubakti, 2012; p. 1-12.

22. Yamin B, Mayulu N, \& Rottie J. Hubungan Asupan Energi Dengan Kejadian Obesitas Pada Siswa Sekolah Dasar Di Kota Manado. Ejournal Keperawatan, 2013;1(1): p. 1-8. Available from https://ejournal.unsrat.ac.id/index.php/jk p/article/view/2165/1723 Diakses pada 17 Maret 2017

23. Sulistyoningsih H. Gizi untuk Kesehatan Ibu dan Anak. Yogyakarta: Graha IImu. 2011;p.52:57-8.

24. Mayasari D. Perbedaan Asupan Energi Protein, Frekuensi jajan Di Sekolah Dan Status Gizi Antara Anak Sekolah Dasar Penerima Dan Bukan Penerima Program Makanan Tambahan Anak Sekolah. Thesis. Semarang: Universitas Diponegoro, 2011; p. 1-35. Available from http://eprints.undip.ac.id/32603/ Diakses pada 17 Maret 2017

25. Gibson S, \& Neate D. Sugar Intake, Soft Drink Consumption and Body Weight Among British Children: Further Analysis of National Diet and Nutrition Survey Data with Adjustment for UnderReporting and Physical Activity. International Journal of Food Sciences and Nutrition. 2007;58(6), p.445-460. Available from http://www.tandfonline.com/doi/full/10. 1080/09637480701288363 Diakses pada 2 Juli 2017

26. Soemarno. Strategi Pemenuhan Kebutuhan Pangan Rumah Tangga Pedesaan. 2010;p.1-105

27. Trentmann C., Latzke U., Julich E., \& Oppeln C.V. Orientation Framework. Sustainable Food and Nutrition Security.
Sixth Report on the World Nutrition Situation. 2015; p.9-25. Available from http://www.welthungerhilfe.de/foodnutrition-security Diakses 14 Maret 2017

28. Hermawati $N$, Sukandar D, \& Khomsan A. Studi Ketahanan Pangan Dan Coping Mechanism Rumah Tangga Di Daerah Kumuh. Surabaya. Bogor: Institut Pertanian Bogor. 2013. Available from http://repository.ipb.ac.id/handle/12345 6789/65809 Diakses pada 2 Juli 2017

29. Rosyadi I, \& Purnomo D. Tingkat Ketahanan Pangan Rumah Tangga Di Desa Tertinggal. Jurnal Ekonomi Pembangunan, 2012;13(2),p. 303-315. Available from http://journals.ums.ac.id/index.php/JEP/ article/view/176 Diakses pada 2 Juli 2017

30. Sukiyono K, Cahyadinata I, \& Sriyoto. Status Wanita Dan ketahanan Pangan Rumah Tangga Nelayan Dan Petani Padi Di Kabupaten Muko-Muko Provinsi Bengkulu. Jurnal Agro Ekonomi, 2008;26(2): p. 191-207. Available from http://repository.unib.ac.id/381. Diakses pada 13 Maret 2017

31. Hadley C, Mulder MB, \& Fitzherbert E. Seasonal Food Insecurity and Perceived Social Support in Rural Tanzania. Public Health Nutrition. 2007;10(6): p. 544-551. Available from http://www.journals.cambridge.org/abstr act_S1368980007246725 Diakses pada 17 Maret 2017.

32. Sujai A, Adiyanti MG, \& Huriyati E. Ketahanan Pangan Rumah Tangga, Status Gizi, dan Prestasi Belajar Siswa Sekolah Dasar. Jurnal Gizi Klinik Indonesia. 2013;9(3): p. 104-110.

33. Isnani Q. 2010. Hubungan Ketahanan Pangan Rumah Tangga Dengan Status Gizi Anak Usia 7-12 Tahun Di Desa Batulicin Kecamatan Batulicin Kabupaten Tanah Bumbu. Skripsi. 2010. 